\title{
EDUKASI PENGGUNAAN MASKER DAN HANDSANITIZER BAGI PETUGAS KEBERSIHAN DI FAKULTAS KEDOKTERAN ULM
}

\author{
Siti Kaidah $^{1}$, Lia Yulia Budiarti², Alfi Yasmina ${ }^{3}$, Farida Heriyani ${ }^{4}$ \\ ${ }^{1}$ Departemen Biomedik Fakultas Kedokteran Universitas Lambung Mangkurat \\ ${ }^{2}$ Departemen Mikrobiologi Fakultas Kedokteran Universitas Lambung Mangkurat \\ ${ }^{3}$ Departemen Farmakologi Fakultas Kedokteran Universitas Lambung Mangkurat \\ ${ }^{4}$ Departemen Ilmu Kesehatan Masyarakat Fakultas Kedokteran Universitas Lambung Mangkurat
}

siti.kaidah@ulm.ac.id, lybudiarti@ulm.ac.id, alfi.yasmina@ulm.ac.id, faridheriyani@yahoo.co.id

\begin{abstract}
Abstrak
Kota Banjarmasin termasuk salah satu kota provinsi dengan jumlah kasus covid-19 terbanyak di Indonesia. Pencegahan terhadap penularan covid-19, diantaranya dengan menerapkan protokol kesehatan berupa penggunaan masker dan mencuci tangan dengan hand sanitizer. Petugas kebersihan yang setiap hari bekerja di Fakultas Kedokteran Universitas Lambung Mangkurat Banjarmasin, termasuk yang berisiko terpapar covid-19. Kegiatan ini bertujuan memberikan pengetahuan dan pemahaman tentang penerapan protokol kesehatan dalam mencegah penularan covid-19. Sasaran kegiatan ini adalah semua petugas kebersihan di FK ULM Banjarmasin. Metode pelaksanaan berupa edukasi online tentang penggunaan masker dan hand sanitizer, serta langkahlangkah mencuci tangan yang baik dan benar. Kegiatan ini juga disertai pembagian masker dan hand sanitizer. Hasil kegiatan, didapatkan peningkatan pengetahuan dan keterampilan dari sasaran. Diharapkan semua peserta kegiatan dapat senantiasa menerapkan protokol kesehatan terkait covid-19 didalam rumah tangga, masyarakat dan di lingkungan kerja.
\end{abstract}

Kata Kunci : covid-19, edukasi online, protokol kesehatan, pencegahan penularan

\section{PENDAHULUAN}

Penyakit infeksi virus corona yang diketahui menjadi wabah pandemi di akhir tahun 2019 (covid-19) dengan cepat menyebar diberbagai belahan dunia termasuk di Indonesia. Kasus positif covid-19 di Indonesia pertama kali dideteksi pada 2 Maret 2020 dan pada 9 April 2020 pandemi covid19 ini sudah menyebar ke 34 provinsi, diantaranya di Kalimantan Selatan (Kalsel) (Ditjen P2P, 2020a). Kasus positif covid-19 di Kalsel pertama kali ditemukan pada 22 Maret 2020 di Kota Banjarmasin, kasus covid-19 di Banjarmasin terus meningkat dan termasuk 10 besar sebagai daerah dengan kasus covid-19 positif terbanyak di
Indonesia (Tim Gugus covid-19 Provinsi Kalsel, 2020; Tim Gugus covid-19 Kota Banjarmasin, 2020).

Penyebaran covid-19 menjadi masif karena virus ini dapat menular antar-manusia melalui droplet. Upaya pencegahan penyebaran infeksi adalah melalui cuci tangan secara teratur menggunakan sabun dan air bersih, menerapkan etika batuk dan bersin, serta menghindari kontak dekat dengan siapapun yang menunjukkan gejala penyakit pernapasan seperti batuk dan bersin (Ditjen P2P, 2020b). 
Pencegahan terhadap penularan covid-19, diantaranya dengan menerapkan protokol kesehatan berupa penggunaan masker dan mencuci tangan dengan hand sanitizer beralkohol dengan konsentrasi $>60 \%$. Penggunaan masker, ditambah dengan pemakaian kaca penutup wajah serta peningkatan personal hiegine mampu meningkatkan perlindungan yang optimum terhadap covid-19 (Mahmood et al., 2020; Sari et al., 2020). WHO menyarankan untuk mencuci tangan selama 20 detik dengan hand sanitizer atau sabun dan air mengalir. Perilaku mencuci tangan diketahui dapat menurunkan mikroorganisme yang terdapat pada tangan hingga 58\% (Situmeang et al., 2019).

Upaya mengantisipasi penularan covid-19 harus dilakukan di banyak tempat, termasuk kantor dan lingkungan kerja. Kantor, sebagai layanan terhadap masyarakat, dapat menjadi ruang penularan virus corona. Kementerian Kesehatan telah menerbitkan Keputusan Menteri Kesehatan Nomor K.01.07/MENKES/328/2020 tentang Panduan Pencegahan dan Pengendalian Covid-19 di Tempat Kerja Perkantoran dan Industri dalam Mendukung Keberlangsungan Usaha pada Situasi Pandemi. Beberapa hal yang harus diperhatikan oleh pekerja dan manajemen perkantoran diantaranya tempat kerja yang bersih dan higienis, penyuluhan cuci tangan, dan penyuluhan kebersihan udara. Kontaminasi permukaan benda yang disentuh oleh pekerja yang terinfeksi virus merupakan salah satu cara utama virus corona dapat menyebar (Kemenkes RI, 2020).

Di sisi lain penyebaran covid-19 dapat berdampak pada perekonomian masyarakat, diantaranya kesulitan memenuhi kebutuhan hidup sebagai akibat dari makin berkurangnya pendapatan, sulit mendapatkan kesempatan bekerja dan pemutusan pekerjaan. Salah satu bidang pekerjaan yang masih dapat dijalani pada saat wabah ini adalah sebagai tenaga kebersihan di suatu kantor/instansi. Di mana hal ini bisa menjadi bagian dari upaya pencegahan penularan covid-19 di tempat kerja/kantor.

Pada saat pandemi covid-19 ini, Fakultas Kedokteran Universita Lambung Mangkurat (FK
ULM) di Banjarmasin termasuk salah satu kantor/instasi pendidikan yang mengikuti aturan pemerintah dengan tetap melaksanakan kegiatan pembelajaran melalui work from home (WHP), tetapi untuk tenaga kebersihan tetap melaksakan tugas dan kewajibannya setiap hari. Petugas kebersihan yang setiap hari bekerja di FK ULM Banjarmasin, termasuk yang berisiko terpapar covid-19. Selain karena tugas pokoknya sebagai tenaga kebersihan, risiko dimaksud juga berkaitan dengan adanya beberapa wilayah kelurahan di kota Banjarmasin yang dikategorikan sebagai zona merah kasus covid-19 (Tim Gugus covid-19 Provinsi Kalsel, 2020; Tim Gugus covid-19 Kota Banjarmasin, 2020). Petugas /tenaga kebersihan di FK ULM merupakan tenaga kontrak outsourcing. Mereka bekerja dengan sistem rolling dan selain bekerja menjaga kebersihan kantor administrasi, WC/kamar mandi, dapur, dan taman, mereka juga bekerja di beberapa labolatorium yang berpotensi berbahaya atau infeksius.

Berdasarkan analisis situasi dan permasalahan di atas, maka diperlukan suatu kegiatan edukasi kepada petugas kebersihan tentang pentingnya penggunaan masker dan cara mencuci tangan yang baik dan benar di masa covid19. Kegiatan penyuluhan ini bertujuan untuk memberikan pengetahuan dan pemahaman tentang penerapan protokol kesehatan dalam mencegah penularan covid-19, khususnya tentang penggunaan masker dan perilaku mencuci tangan yang baik dan benar. Diharapkan petugas kebersihan di lingkungan FK ULM senantiasa berperilaku menerapkan protokol kesehatan di masa covid-19, tidak hanya di tempat kerja tapi juga di lingungan rumah tangga dan di masyarakat.

\section{METODE}

Pendekatan yang dilakukan berupa pemberian promosi kesehatan bagi semua petugas kebersihan di FK Banjarmasin, yaitu berupa penyuluhan tentang penggunaan masker dan hand sanitizer, serta langkah-langkah mencuci tangan yang baik dan benar. Metode pelaksanaan berupa edukasi penyuluhan secara online. Selain itu promosi ini dilakukan dengan pemberian masker dan hand sanitizer bagi tenaga kebersihan FK ULM

$$
\text { Kesehatan }
$$


Banjarmasin, agar mereka terbiasa untuk melaksankan protokol kesehatan di tempat bekerja, di lingkungan rumah dan di masyarakat. .

Penyampaian materi dan edukasi cara penggunaan masker dan mencuci tangan dilakukan melalui demo video secara online, Peralatan yang digunakan terdiri dari jaringan webinar, LCD proyektor, laptop, masker, hand sanitizer, air mencuci tangan, dan wastafel. Sebelum kegiatan, terlebih dahulu dilakukan sosialisasi dan koordinasi dengan semua peserta kegiatan melalui grup WhasApp agar dapat berhadir dan mengikuti kegiatan sesuai kesepakatan.

Pelaksanaan kegiatan penyuluhan diawali dengan pemberian pretes pengetahuan dari semua peserta kegiatan untuk mengetahui pengetahuan awal mereka tentang penggunaan masker dan hand sanitizer, serta langkah-langkah mencuci tangan yang baik dan benar. Kegiatan dilanjutkan dengan memberikan penyuluhan tentang risiko dan pencegahan penularan covid- 19. Penyuluhan dilakukan dengan metode ceramah ditambah dengan tanya jawab dan diskusi dengan sasaran kegiatan untuk mengetahui pemahaman dari peserta kegiatan. Keseluruhan kegiaatan ini dilakukan secara online.

Media penyuluhan berupa video peragaan/demo penggunaan masker dan langkahlangkah mencuci tangan yang baik dan benar dengan bantuan layar LCD proyektor, untuk mempemudah pemberian materi dan pemahaman pada semua peserta kegiatan dan juga dapat diikuti oleh seluruh peserta kegiatan dengan tetap menjaga jarak (social distanching).

Sasaran pada kegiatan ini adalah petugas kebersihan di FK ULM Banjarmasin yaitu sebanyak 10 orang. Namun pada pelaksanaan kegiatan ada tambahan peserta yaitu 5 orang petugas keamanan dan petugas parkir. Kegiatan penyuluhan ini dilaksanakan pada 25 April 2020 bertempat di labolatorium Mikroskopis FK ULM Banjarmasin, yang kapasitas daya tampung orang pada posisi duduk sebanyak 80 orang. Jumlah peserta kegiatan yang hanya 15 orang memudahkan pengaturan jarak tempat duduk peserta kegiatan sesuai ketentuan social distancing.

Kegiatan diakhiri dengan pemberian postest kepada peserta menggunakan pertanyaan yang sama dengan pretest secara online untuk mengetahui pemahaman mereka tentang materi penyuluhan dan sebagai salah satu indikator keberhasilan kegiatan ini. Dilanjutkan dengan pemberian masker dan hand sanitizer kepada semua peserta kegiatan.

\section{HASIL DAN PEMBAHASAN}

Telah dilaksanakan kegiatan pengabdian masyarakat berupa edukasi pemberian promosi kesehatan melalui penyuluhan secara online kepada petugas kebersihan di lingkungan FK ULM Banjarmasin; materi penyuluhan mengenai pentingnya menggunakan masker dan mencuci tangan yang baik dan benar, yang merupakan bagian dari penerapan protokol kesehatan di masa covid-19, sebagai upaya pencegahan terhadap paparan infeksi virus corona. Selain itu edukasi ini dilakukan dengan pemberian peragaan/demo video tentang penggunaan masker serta mencuci tangan yang baik dan benar. Kemudian pada tiap peserta diberikan hand sanitizer dan masker; dimaksudkan untuk membantu peserta membiasakan diri mencuci tangan saat di tempat bekerja, di rumah dan saat beraktivitas di lingkungan masyarakat, dan menggunakan masker saat beraktivitas ke luar rumah dan di tempat bekerja.

Kegiatan ini dilaksanaakan dengan tujuan untuk meningkatkan pengetahuan dan kesadaran patugas kebersihan yang berisiko mendapat paparan infeksi covid-19. Diharapkan petugas kebersihan/ semua peserta kegiatan dapat menerapkan dan membiasakan diri menggunkan masker dan mencuci tangan sebagai bagian dari protokol kesehatan, sehingga dapat terhindar dari paparan covid-19. Selain itu pembiasaan diri menerapkan protokol kesehatan di masa covid-19 ini dapat menjadi contoh perilaku hidup bersih dan sehat dalam keluarga dan di masyarakat.

Pada pelaksanaan kegiatan penyuluhan, diawali dengan pemberian pretes untuk mengetahui pengetahuan awal peserta tentang penggunaan masker dan mencuci tangan yang baik dan benar sebagai bagian dari penerapan prootokol kesehatan di masa covid-19. Peserta kegiatan adalah sebayak 15 orang, yang terdiri dari petugas kebersihan, petugas keamanan, dan petugas parkir. Berikut disajikan hasil pretest pengetahuan peserta kegiatan 
tentang penggunaan masker serta Langkah-langkah mencuci tangan yang baik dan benar.

Tabel 1. Hasil pretest pengetahuan petugas kebersihan/peserta kegiatan tentang penggunaan masker serta langkah-langkah mencuci tangan yang baik dan benar

\begin{tabular}{ccc}
\hline Pengetahuan & $\begin{array}{l}\text { Jumlah } \\
\text { peserta }\end{array}$ & Persentase (\%) \\
\hline Baik & 2 & 13,33 \\
\hline Cukup & 4 & 26,67 \\
\hline Kurang & 9 & 60,00 \\
\hline Jumlah & 15 & 100 \\
\hline
\end{tabular}

Berdasarkan tabel 1 diketahui bahwa sebagain besar $(60,00 \%)$ peserta kegiatan masih mempunyai pengetahuan kurang, 26,67\% peserta mempunyai pengetahuan cukup dan hanya $13,33 \%$ yang mempunyai pengetahuan baik. Hal ini menunjukkan masih rendahnya pengetahuan dari peserta kegiatan tentang penggunaan masker serta langkah-langkah mencuci tangan yang baik dan benar. Padahal penerapan protokol kesehatan di masa covid-19 yang utama adalah penggunaan masker dan seringnya mencuci tangan dengan hand sanitizer atau sabun cuci tangan dan air mengalir. Data ini mendukung diperlukannya pemberian promosi kesehatan kepada petugas kebersihan di lingkungan FK ULM Banjarmasin.

Kegiatan dilanjutkan dengan memberikan penyuluhan tentang risiko paparan covid-19 dan pencegahan penularan covid-19. Penyuluhan dilakukan dengan penayangan slide materi, penayangan video cara penggunaan masker dan video langkah-langkah mencuci tangan yang baik dan benar, ditambah dengan tanya jawab dan diskusi dengan sasaran kegiatan untuk mengetahui pemahaman sasaran kegiatan. Media penyuluhan berupa layar LCD proyektor dan semua kegiatan dilaksanakan secara online, semua peserta berada dalam suatu ruangan dengan luas yang memadai dan menerapkan protokol jaga jarak (social distanching) di antara para peserta. Pelaksanaan secara online dengan memberikan kesempatan diskusi intraktif mempermudah pemberian materi dan pemahaman pada sasaran kegiatan.

Kegiatan diakhiri dengan pemberian postest secara online kepada semua peserta menggunakan pertanyaan yang sama dengan pretest untuk mengetahui pemahaman mereka tentang materi penyuluhan dan sebagai salah satu indikator keberhasilan kegiatan ini. Berikut pada tabel 2 disajikan hasil posttest.

Tabel 2. Hasil postest pengetahuan petugas kebersihan/peserta kegiatan tentang penggunaan masker serta langkah-langkah mencuci tangan yang baik dan benar

\begin{tabular}{ccc}
\hline Pengetahuan & $\begin{array}{c}\text { Jumlah } \\
\text { peserta }\end{array}$ & Persentase (\%) \\
\hline Baik & 15 & 100 \\
\hline Cukup & 0 & 0 \\
\hline Kurang & 0 & 0 \\
\hline Jumlah & 15 & 100 \\
\hline
\end{tabular}

Berdasarkan tabel 2 diketahui tingkat pengetahuan peserta setelah dilakukan penyuluhan. Didapatkan semua peserta (100\%) memiliki pengetahuan yang baik tentang penggunaan masker serta langkah-langkah mencuci tangan yang baik dan benar.

Nilai ini menunjukkan bahwa setelah dilakukan edukasi berupa penyuluhan dan demonstrasi secara online telah terjadi peningkatan pengetahuan tentang penerapan penggunaan masker serta langkah-langkah mencuci tangan yang baik dan benar pada para petugas kebersihan yang menjadi peserta kegiatan ini. Jadi dapat diambil kesimpulan bahwa kegiatan edukasi berupa penyuluhan secara online tentang penggunaan masker serta langkah-langkah mencuci tangan yang baik dan benar telah berhasil meningkatkan pengetahuan peserta kegiatan.

Kegiatan dilanjutkan dengan pembagian masker dan hand sanitizer kepada seluruh peserta kegiatan sebagai contoh dan dapat digunakan untuk menerapkan pengetahuan yang telah mereka dapatkan sesuai protokol kesehatan di masa covid19. Diharapkan para peserta dapat menjadi contoh dalam berperilaku hidup bersih dan sehat di masa covid-19 di tempat bekerja, saat di rumah dan saat berada di masyarakat/di luar rumah. Selanjutnya penerapan perilaku hidup bersih dan sehat dan penerapan protokol kesehatan ini dapat mencegah masyarakat dari paparan covid-19.

Kesehatan 302 
Evaluasi terhadap adanya komitmen dari sasaran dalam menerapkan pengetahuan yang diperoleh dilakukan selama 2 minggu berturut-turut setelah kegiatan penyuluhan. Hasil pengamatan menunjukkan bahwa masing-masing sasaran sudah menggunakan masker ketika tiba di tempat kerja dan selama bekerja hingga pulang kembali dari tempat kerja. Petugas kebersihan dan satpam Fakultas Kedokteran juga didapatkan lebih sering memanfaatkan sarana cuci tangan dengan sabun serta hand sanitizer yang tersedia di beberapa tempat strategis di lingkungan kampus. Dapat disimpulkan bahwa penyuluhan yang dilakukan berhasil meningkatkan pengetahuan sekaligus kesadaran sasaran untuk berperilaku hidup bersih sesuai anjuran.

Memperhatikan hasil kegiatan dan kenyataan bahwa sebagian besar sasaran bekerja membersihkan lingkungan kampus di mana terdapat banyak sarana toilet dan beberapa laboratorium yang berpotensi menjadi tempat penularan penyakit, dirasa perlu melakukan penyuluhan lanjutan terkait kebersihan dan keselamatan kerja bagi sasaran. Untuk menilai hasil kegiatan penyuluhan lanjutan ini, selain mengukur perubahan pengetahuan, dipandang perlu melakukan pengukuran perubahan sikap dari sasaran.

Penularan virus corona (covid-19) dari manusia ke manusia adalah melalui percikan batuk/bersin (droplet). Seseorang berisiko tertular covid-19 ketika seseorang berkontak erat dengan penderita melalui percikan droplet ketika batuk/bersih atau melalui droplet yang menempel pada tangan. Selain itu, setiap orang yang terinfeksi, dengan atau tanpa gejala, dapat menyebarkan virus dengan menyentuh permukaan benda. Droplet yang dihasilkan ketika orang yang terinfeksi batuk atau bersin dapat mendarat di mulut atau hidung orangorang yang berada di dekatnya, atau terhirup ke dalam paru-paru. Seseorang yang terinfeksi virus corona yang tanpa gejala, juga dapat mengeluarkan droplet ketika berbicara atau bernapas. Droplet adalah partikel virus infeksius yang dapat melayang di udara sampai sekitar tiga jam, dapat terinhalasi/terhirup dan menginfeksi paru-paru seseorang. Inilah sebabnya mengapa setiap orang harus menutup hidung dan mulut (Ditjen P2P, 2020b; Havard Medical School, 2020).
Pencegahan paparan dan upaya mencegah meluasnya penyebaran covid-19 di wilayah tertentu, dilakukan dengan pembatasan sosial berskala besar (PSBB). Pembatasan sosial ini dilakukan oleh semua orang di wilayah yang diduga terinfeksi penyakit. Dengan jaga jarak mengacu pada tindakan untuk menghentikan atau memperlambat penyebaran penyakit menular. Pencegahan pada level masyarakat dapat dilakukan dengan pembatasan interaksi fisik dan pembatasan sosial (Physical contact/physical distancing dan social distancing) dan menerapkan etika batuk dan bersin. Menjaga jarak/ physical distancing; jarak yang cukup aman adalah 1-2 meter antara orang ke orang-orang lainnya untuk menghindari infeksi atau menginfeksi orang lain (Ditjen P2P, 2020b).

Pencegahan pada tingkat individu dilakukan dengan menjaga kebersihan diri dan lingkungan rumah, meningkatkan imunitas diri dan mengandalikan komorbid. Perilaku menjaga kebersihan diri dengan sering mencuci tangan dengan air mengalir dan sabun atau menggunakan pembersih tangan berbasis alkohol (hand sanitizer), menghindari menyentuh mulut, hidung, dan mata dengan tangan yang belum dicuci, menghindari berjabat tangan dengan orang lain, menghindari interaksi dekat dengan orang sakit, atau menggunakan masker jika harus keluar rumah atau bertemu dengan orang lain, serta membersihkan dan memberikan desinfektan secara berkala pada bendabenda yang sering disentuh (Ditjen P2P, 2020b). Virus corona juga dapat tetap berada dalam droplet yang berada di permukaan benda dan permukaan kulit tangan yang menyentuhnya dan kemudian dapat mengenai bagian mulut, hidung atau mata yang disentuh/diraba oleh tangan. Sehingga sangat penting untuk menghindari menyentuh permukaan di tempat umum atau terlebih dahulu gunakan desinfektan untuk menyeka permukaan benda.

Kementerian kesehatan RI telah merekomendasikan protokol kesehatan sebagai cara mencegah penyebaran infeksi covid-19, diantaranya adalah melakukan perilaku mencuci tangan secara teratur menggunakan hand sanitizer atau sabun cuci tangan dan air bersih, menerapkan etika batuk dan bersin, menghindari kontak secara langsung atau dekat dengan siapapun yang menunjukkan gejala penyakit pernapasan seperti batuk dan bersin, serta 
menggunakan masker disaat berada di luar rumah atau saat sakit (Ditjen P2P, 2020b).

Penerapan protokol kesehatan sangat penting untuk dilakukan oleh semua lapisan masyarakat dan harus dilakukan di banyak tempat, termasuk kantor dan lingkungan kerja. Para pekerja dapat melaksanakan protokol kesehatan sesuai dengan panduan pencegahan dan pengendalian covid-19 di tempat kerja yang diterbitkan oleh Kementerian kesehatan berdasarkan Keputusan Menteri Kesehatan Nomor K.01.07/MENKES/328/2020. Panduan dari kemenkes tersebut terdiri dari upaya pencegahan dan pengendalian Covid-19 dilingkup kerja perkantoran dan perindustrian selama pembatasan sosial berskala besar (PSBB ) dan pasca PSBB; diantaranya tercantum prinsip-prinsip pencegahan covid-19 dengan menggunakan masker, menjaga jarak, mencuci tangan pakai sabun, meningkatkan daya tahan tubuh dan makan makanan bergizi. Panduan ini berlaku untuk seluruh komponen yang terlibat dan menyesuaikan kondisi di tempat kerja.

Perilaku yang dianjurkan untuk sering dilakukan saat wabah covid-19 adalah mencuci tangan dengan hand sanitizer atau dengan sabun dan air mengalir. Menurut WHO, mencuci tangan agar bersih menghabiskan waktu sekitar 20-30 detik; mengingikuti Langkah-langkah/cara cuci tangan yang baik dan benar menurut WHO, terbukti dapat menurunkan jumlah populasi/kolonisasi mikroorgnaisme pada tangan dan mencegah paparan/terinfeksi virus, bakteri dan mkroorganisme lainnya. Kandungan zat kimia utama yang terdapat dalam hand sanitizer adalah alkohol. Penggunaan akohol antara 60-80\% diketahui lebih efektif dalam menurunkan jumlah kolonisasi mikroba pada tangan (Asngad et al., 2018; Iskandar \& Yanto, 2018; Kusuma et al., 2019; Pittet, 2009).

Kegiatan cuci tangan dilakukan terutama setelah pergi ke kamar mandi/WC; sebelum makan; setelah memegang hidung, batuk, atau bersin; dan setelah menyentuh /memegang benda di luar rumah (Ditjen P2P, 2020b; Kemenkes RI, 2020; Pittet, 2009). Pastikan selalu mencuci tangan setiap usai melakukan atau menyentuh sesuatu, terutama di tempat umum
Langkah-langkah mencuci tangan yang baik dan benar sesuai panduan WHO dilakukan dalam 7 langkah yaitu: 1). Basahi tangan dan tuangkan atau oleskan produk sabun di telapak tangan. 2). Tangkupkan kedua telapak tangan dan gosokkan produk sabun yang telah dituangkan. 3). Letakkan telapak tangan kanan di atas punggung tangan kiri dengan jari yang terjalin dan ulangi untuk sebaliknya. 4). Letakkan telapak tangan kanan ke telapak tangan kiri dengan jari saling terkait. 5). Tangan kanan dan kiri saling menggenggam dan jari bertautan agar sabun mengenai kuku dan pangkal jari. 6). Gosok ibu jari kiri dengan menggunakan tangan kanan dan sebaliknya. 7). Gosokkan jari-jari tangan kanan yang tergenggam di telapak tangan kiri dan sebaliknya. Bilas dan keringkan tangan dengan handuk atau kain sapu tangan (Kemenkes RI, 2020; Pittet, 2009).

Penerapan protokol kesehatan lainnya bagi masyarakat yang beraktivitas di luar rumah atau bekerja di suatu kantor adalah penggunakan masker non medis. Masker kain non medis yang digunakan secara benar, dapat mengurangi resiko paparan covid-19. Menurut WHO, pedoman tentang komposisi masker kain non-medis untuk masyarakat umum, harus terdiri dari setidaknya tiga lapisan bahan yang berbeda. Lapisan paling dalam harus terbuat dari bahan penyerap air seperti kapas dan bahan yang lembut lantaran bersentuhan langsung dengan kulit. Lapisan tengah, yang berfungsi sebagai filter terbuat dari bahan seperti polipropilena non-anyaman. Lapisan luar harus terbuat dari bahan yang tahan air seperti polyester (World Health Organization, 2020). Bahan katun dapat digunakan sebagai masker kain. Perlu diperhatikan tentang cara penggunaan dan perawatan masker kain yang tepat; masker kain dapat dipakai maksimal hanya 4 jam, masker kain perlu dicuci dan dapat dipakai berkali-kali. Cara menggunakan masker yang tepat adalah masker menutupi bagian hidung dan mulut. Setelah digunakan dari luar rumah, saat masker dilepas, cukup dengan menarik bagian tali dan langsung disimpan pada kantong kertas atau plastik tertutup (Biro Komyanmas Kemenkes RI, 2020; Sari et al., 2020).

Kesehatan 304 


\section{KESIMPULAN}

Telah dilakukan kegiatan edukasi online penggunaan masker dan hand sanitizer bagi petugas kebersihan di FK ULM Banjarmasin. Dari hasil kegiatan didapatkan ada peningkatan pengetahuan dari sasaran. Diharapkan semua peserta kegiatan dapat senantiasa menerapkan protokol kesehatan terkait covid-19 didalam rumah tangga, masyarakat dan di lingkungan kerja.

Disarankan untuk dilakukan penyuluhan lanjutan terkait upaya-upaya yang harus dilakukan oleh sasaran dalam rangka memelihara kesehatan dan keselamatan di tempat kerja, dan untuk menilai keberhasilan kegiatan penyuluhan disarankan melakukan pengukuran perubahan pengetahuan dan sikap sasaran antara sebelum dan sesudah kegiatan.

\section{UCAPAN TERIMAKASIH}

Ucapan terima kasih kami sampaikan atas partisipasi berbagai pihak yang membantu pelaksanaan kegiatan ini, yaitu:

1. Staf/ tenaga kebersihan dan tenaga honorer Fakultas Kedokteran ULM Banjrmasin.

2. Staf/ tenaga administrasi penunjang Pendidikan Fakultas Kedokteran ULM Banjarmasin.

\section{REFERENSI}

Asngad, A., Bagas, A. R., \& Nopitasari. (2018). Kualitas Gel Pembersih Tangan (Handsanitizer) dari Ekstrak Batang Pisang dengan Penambahan Alkohol, Triklosan dan Gliserin yang Berbeda Dosisnya. Bioeksperimen, 4(2), 61-70.

Biro Komyanmas Kemenkes RI. (2020). Begini Aturan Pemakaian Masker Kain yang Benar. https://www.kemkes.go.id/article/view/2006090000 2/begini-aturan-pemakaian-masker-kain-yangbenar.html

Ditjen P2P. (2020a). Pedoman Pencegahan dan Pengendalian Coronavirus Disease (Covid-19). Rev-04 (Rev-04). Kementrian Kesehatan RI.

Ditjen P2P. (2020b). Pedoman Pencegahan dan Pengendalian Coronavirus Disease (Covid-19). Rev-05 (Rev-05). Kementrian Kesehatan RI.
Havard Medical School. (2020). Preventing the spread of infection. In Harvard Health Publishing https://doi.org/10.12968/jorn.2011.3.5.212

Iskandar, M. B., \& Yanto, A. (2018). Pengaruh Pendidikan Kesehatan terhadap Pelaksanaan Cuci Tangan 6 Langkah 5 Momen Keluarga Pasien di Ruang Rawat Inap RS Roemani Semarang dirawat, termasuk rumah sakit . Mencuci tangan merupakan rutinitas yang murah dan penting perkembangbiakan mikroorga. Prosiding Seminar Nasional Mahasiswa Unimus, 1, 120-128.

Kemenkes RI. (2020). Keputusan menteri kesehatan republik indonesia nomor hk.01.07/menkes/328/2020 tentang PANDUAN PENCEGAHAN DAN PENGENDALIAN CORONA VIRUS DISEASE 2019 (COVID-19) DI TEMPAT KERJA PERKANTORAN DAN INDUSTRI DALAM MENDUKUNG KEBERLANGSUNGAN USAHA PADA SITUASI PANDEMI.

Kusuma, Y., Pinatih, K. J. P., \& Hendrayana, M. A. (2019). EFEK SINERGIS KOMBINASI CHLORHEXIDINE DAN ALKOHOL TERHADAP DAYA HAMBAT PERTUMBUHAN STAPHYLOCOCCUS AUREUS. E-Jurnal Medika, 8(3), 139-146.

Mahmood, A., Eqan, M., Pervez, S., Ahmed, H., \& Bari, A. (2020). COVID-19 and frequent use of hand sanitizers; human health and environmental hazards by exposure pathways. Sci Total Environ., 742, 1-7.

Pittet, D. (2009). WHO Guidelines on Hand Hygiene in Health Care: a Summary; First Global Patient Safety Challenge Clean Care is Safer Care. In World Health Organization (Vol. 30, Issue 1).

Sari, D. P., Sholihah, N., \& Atiqoh. (2020). Hubungan antara pengetahuan masyarakat dengan kepatuhan penggunakan masker sebagai upaya pencegahan penyakit COVID-19 di Ngronggah. INFOKES Journal, 10(1), 52-55.

Situmeang, Suryani MF, and Teranguli J. Sembiring. Efektivitas hand sanitizer dalam membunuh kuman di tangan. Jurnal AnLabMed Analis Laboratorium Medis 1.1 (2019): 6-11 
Tim Gugus Tugas Penanganan Covid-19. (2020). Jumlah Kasus Covid-19 di Indonesia. Kementerian Kesehatan RI : Jakarta.

Tim Gugus Tugas Penanganan Covid-19 Provinsi Kalimantan Selatan. (2020). Jumlah Kasus Covid-19 di Kalimantan Selatan. Dinas Kesehatan Provinsi Kalsel : Banjarmasin.

Tim Gugus Tugas Penanganan Covid-19 Kota Banjarmasin. (2020). Jumlah Kasus Covid-19 di Kota Banjarmasin. Dinas Kesehatan Kota Banjarmasin : Banjarmasin.

World Health Organization. (2020). Advice on the use of masks in the context of COVID-19: interim guidance-2. In WHO Publications (Issue 6 April, pp. 1-5). WHO Publications. 